\title{
Miejsce kościoła w strukturze wsi na przykładzie wybranych wsi polskiego Zamagurza Spiskiego
}

\section{The place of the church in the structure of the village on the example of selected villages of the Polish Zamagurze Spiskie}

\section{Streszczenie}

Artykuł dotyczy problematyki lokalizacji i roli kościoła w historycznych strukturach wiejskich w powiązaniu z życiem społeczności. Na podstawie wybranych wsi polskiej części Zamagurza Spiskiego wskazano czynniki warunkujące główne przekształcenia struktur od czasu powstania do współczesności. Badany obszar, zróżnicowany krajobrazowo, był miejscem styku prądów kulturowych, religijnych oraz politycznych. W efekcie powstały odmienne morfologicznie układy, w których funkcjonowanie instytucji kościelnych, będąc każdorazowo wyrazem potrzeb religijnych społeczności, warunkowane było silnie przez specyfikę miejsca, w tym krajobraz.

Słowa kluczowe: kościół, Zamagurze Spiskie, struktura wsi, układ niwowy, układ łanowy

\section{Abstract}

This article deals with the problem of the place of the church in historical rural structures in connection with the life of the community. On the basis of selected villages of the Polish part of Zamagurze Spiskie, the factors determining the main transformations of structures from the time of their inception to the present day have been identified. The studied area, diversified in terms of landscape, was a meeting point of cultural, religious and political trends. As a result, morphologically different systems were created, in which the functioning of church institutions, each an expression of the religious needs of the community, was strongly conditioned by the specificity of the place, including the landscape.

Keywords: church, Zamagurze Spiskie, village structure, field system, joined-field system 


\section{WPROWADZENIE}

Kościół zawsze zajmował szczególne miejsce w strukturze wsi jako regulator życia społeczności, na co wskazują liczne badania, m.in.: religioznawców, historyków, etnografów czy socjologów. W swoim artykule dotyczącym kościołów Małopolski Marian Kornecki (1992), wskazał ich rolę jako dominant przestrzennych i obiektów reprezentacyjnych, górujących jednocześnie w wymiarze ideowym jako ośrodki kultu, znaki wspólnoty i społecznej organizacji. Uosabiały one, oparty na religii, kanon norm życiowych, głoszonych przez plebana cieszącego się niepodważalnym autorytetem nauczyciela i opiekuna. Socjolożka wsi, Izabella Bukraba-Rylska (2013), wskazała również, oprócz wpływu zasad wiary na życie codzienne, tworzenie partykularnej tożsamości lokalnej, spajającej określoną przestrzennie grupę społeczną wokół miejsca kultu.

Celem niniejszego artykułu jest wskazanie głównych czynników określających umiejscowienie kościoła w strukturze przestrzennej wsi. Przeprowadzone analizy obejmują przekształcenia zachodzące od początków formalnego osadnictwa do dzisiaj na obszarze polskiej części Zamagurza Spiskiego. Wybrane do analiz wsie, Frydman i Czarna Góra, o odmiennych uwarunkowaniach lokalnych, cechuje stan zachowania, rozwój gospodarczy oraz posiadane zasoby kulturowe czyniące je reprezentatywnymi dla badanych problemów przekształceń (Korzeniowska, 2021).

Zastosowaną metodą badawczą są studia literatury z zakresu historii ruralistyki (Chowaniec, 1986; Burszta, 1958; Szulc, 1995). Źródłami informacji na temat Zamagurza Spiskiego i zamagurskich wsi są badania opublikowane w licznych opracowaniach (Solecki, 1966; Trajdos, 1991, 2011a; Budz, 1999; Złahoda, 1995; Janicka-Krzywda i in., 2011, 2012). Powyższe dane historyczne zostały wsparte badaniami własnymi autorki, obejmującymi wizyty terenowe przeprowadzone w latach 2018-2020 oraz analizy historycznych i współczesnych materiałów kartograficznych.

\section{ZAMAGURZE SPISKIE}

Zamagurze Spiskie jest obszarem etnograficznym oraz subregionem geograficznym należącym do Spisza obejmującego tereny Polski i Słowacji. Leżący w granicach południowej Małopolski teren jest typowo wiejski, podzielony na 15 wsi z gmin Nowy Targ, Łapsze Niżne oraz Tatrzańska (il. 1). Ze względu na uwarunkowania naturalne i zasoby kulturowe jest częścią polsko-słowackiego regionu turystycznego.

Zamagurskie osadnictwo w obszarze transgranicznym ukształtowane było przez mieszankę kultur i narodowości wnoszących rodzime sposoby oraz formy zamieszkania i funkcjonowania, dostosowane do lokalnych uwarunkowań. Za początek polskich struktur uznaje się przybycie plemion słowiańskich w XI wieku, dających początek osadom na prawie polskim¹.

Kolonizacja prowadzona była głównie przez klasztory przy pomocy zamieszkującej teren ludności polskiej przybyłej do doliny Dunajca. Osadnikami byli najczęściej chłopi otrzymujący działki w bezterminową dzierżawę, będący pod zarządem starosty wyznaczonego przez właściciela wsi. Układy miały zazwyczaj skoncen- 


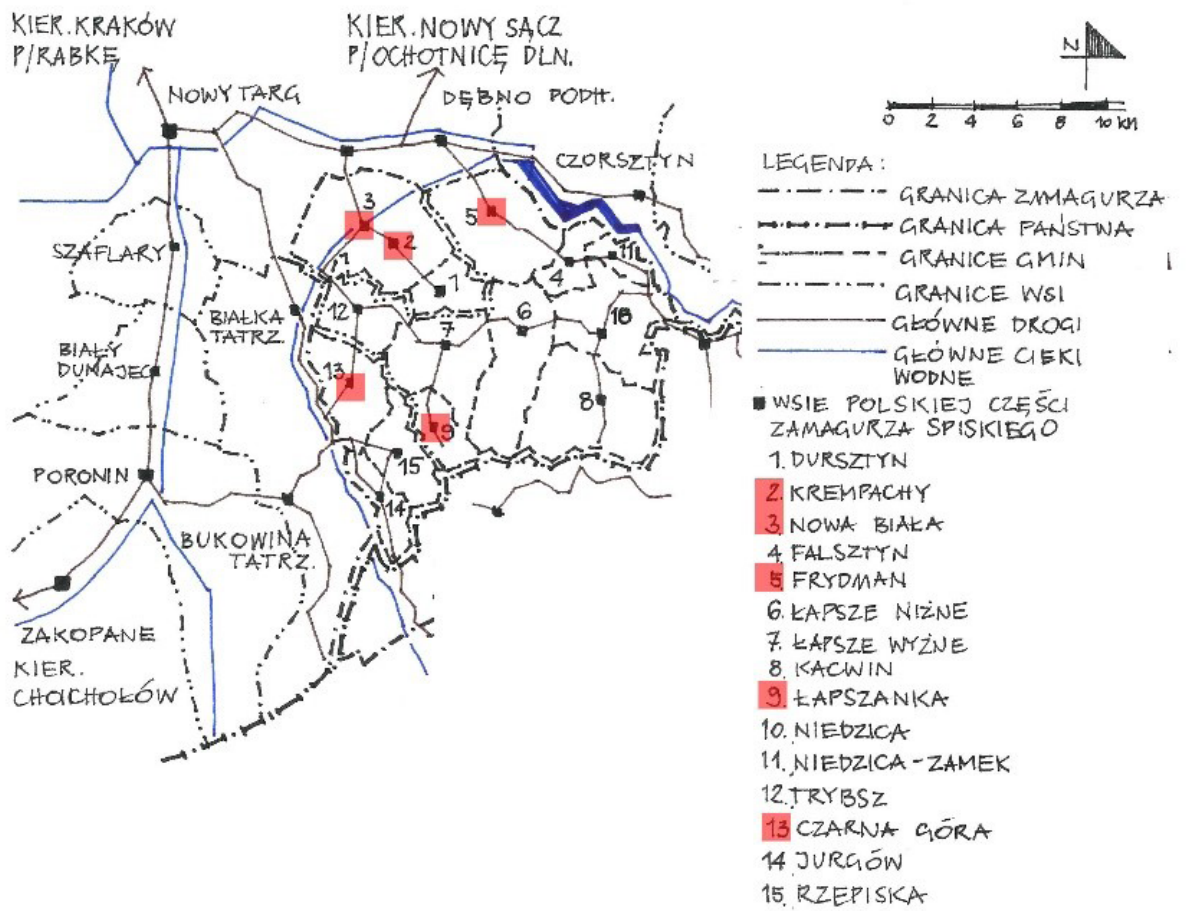

II. 1. Schemat rozmieszczenia wsi polskiej części Zamagurza Spiskiego. Oprac. własne

Kolejno, na początku XIV wieku po przekazaniu ziem na rzecz Węgier miejscowa szlachta objęła je akcją kolonizacyjną na prawie magdeburskim (Radziszewska, 1985), będącą częścią europejskiej fali migracyjnej podążającej z przeludnionych Niemiec na wschód². Celem działań było zasiedlenie granicznego pasa nowo zdobytego terytorium. Rozwijając stan posiadania, feudałowie rozbudowywali folwarki oraz lokowali nowe ośrodki w ramach kolonizacji wołoskiej. Zwłaszcza kolonizacja w wyżynnych terenach południowo-wschodniej części Zamagurza opierała się na przybyłych z głębi Karpat wędrownych pasterzach - Wołochach. Zasady ustroju polityczno-gospodarczego były połączeniem tradycji rdzennej ludności z prawem niemieckim oraz węgierskim. Każdy z osadników dostawał odpowiedni nadział ziemi w postaci łanu („zarębka”). Zasiedlony wielokulturowo obszar zmieniał często zarządców, przechodząc w 1769 roku w granice Austrii oraz w 1867 roku w ręce Austro-Węgier, gdzie pozostał do zakończenia I wojny światowej. W 1920 roku, na krótko, teren Spisza został

trowane siedlisko w formie owalnicy, wokół której, pomiędzy lasami, szachownicowo rozmieszczone były pola uprawne.

2 Założeniem prawa magdeburskiego było stworzenie atrakcyjnych warunków, w celu przyciągnięcia osadników niemieckich, w postaci licznych przywilejów i ulg realizowanych w formach przestrzennych kontynuujących znane im i sprawdzone zasady funkcjonowania. 
podzielony pomiędzy Czechosłowację oraz Polskę, kształtując przebieg granicy państwowej przybliżony do dzisiejszego, do którego powrócił trwale w 1945 roku. Działalność kolejnych państw zaznaczyła się każdorazowo reformami o zakresie lokalnym lub szerszym, państwowym. W XVI wieku ruchy reformacji i kontrreformacji powodowały, oprócz krwawych sporów szlacheckich, konieczność okresowych zmian wyznania w lokalnych kościołach. Narzucenie języka (głównie węgierskiego i słowackiego) w religii i edukacji było niezmiennie jednym z narzędzi polityki narodowościowej i kontroli nad miejscową ludnością.

Efektem realizacji działań osadniczych w zróżnicowanym terenie Zamagurza było wytyczanie odmiennych w założeniach i sposobie funkcjonowania osadniczych struktur wiejskich na zasadach gruntowego rozplanowania: niwowego oraz łanowego (Burszta, 1958; Chowaniec, 1986; Szulc, 1995). Pierwszy typ, stosowany powszechnie w lokacjach wsi rolniczych na prawie magdeburskim od XIV wieku, opierał się na regularnych podziałach gruntów realizujących gospodarkę wspólnotową trójpolówki zbiorowej. Stosowano go we wsiach pasa południowo-wschodniego, m.in. takich jak: Krempachy, Nowa Biała, Frydman, gdzie w szerokich dolinach rzecznych ze względu na ukształtowanie oraz uwarunkowania glebowe możliwa była gospodarka rolna oraz realizacja ustalonych zasad podziału struktury, którą cechowały regularne zasady podziału funkcji i własności. Centrum układu stanowiło nawsie, czyli prostokątny w zarysie wspólnotowy plac gospodarczy, ograniczony drogami obsługującymi regularne pierzeje zabudowy zagrodowej. Rozplanowanie łanowe stosowane było natomiast w układach prawa wołoskiego wsi Czarna Góra czy Łapszanka powstałych w górzystej południowej strefie wąskich dolin potoków. Ze względu na brak możliwości terenowych do wydzielenia wspólnych stref, teren dzielony był na równoległe pasy, uprawiane na zasadzie trójpolówki indywidulanej. Skupiska zagród na działkach siedliskowych rozmieszczone były luźno, wzdłuż głównej drogi biegnącej doliną cieku, tworząc rozproszoną strukturę łańcuchową. Obydwie zasady wytworzyły odmienne układy morfologiczne charakterystyczne dla Spisza oraz, szerzej, południowej Małopolski.

\section{FRYDMAN}

Słownik geograficzny Królestwa Polskiego i innych krajów słowiańskich, wydany w 1880 roku, opisuje Frydman jako „(...) wś na Podhalu Spiskim (Węgry), na pograniczu Galicyi z Węgrami (...). Do parafii frydmańskiej wchodzą Frydman, Falsztyn i Równa, ogółem 1228 dusz rz. kat., 4 prot., 160 szyzm., 39 żydów, z czego na Frydman przypada 1086 dusz rz. kat., 4 prot., 131 szyzm., 29 żydów (...)" (Sulimierski i in., 1880: 419).

Frydman położony we wschodniej części gminy Łapsze Niżne w powiecie nowotarskim jest drugą pod względem wielkości i trzecią w zakresie zaludnienia wsią zamagurską. Głównym kierunkiem gospodarki lokalnej jest rozwijająca się powoli turystyka bazująca na 
uwarunkowaniach krajobrazowych i kulturowych oraz powiązaniach regionalnych. Historycznie dominujące rolnictwo ichów bydła znacząco osłabłyna skutekzmian polityczno-gospodarczych.

Pierwsze osadnictwo na obszarze Frydmana potwierdzają wczesnośredniowieczne znaleziska archeologiczne odkryte w rejonie dzisiejszej ulicy Kamienne Pole, tj. na południowy zachód od układu lokacyjnego (Niemiec, 2011). Formalną lokację wsi na prawie magdeburskim w 1308 roku przeprowadził węgierski szlachcic Kokosz Berzewiczy, adaptując, prawdopodobnie, funkcjonującą już osadę na prawie polskim (Trajdos, 2011a). Brak jest informacji na temat ówczesnego kształtu wsi, jednak opierając się wskazaniach Burszty (1958), można przypuszczać, że była to owalnica, w której kościół zajmował centralne miejsce. Badania archeologiczno-architektoniczne kościoła pw. św. Stanisława Męczennika, których wyniki przytoczono w publikacji Trajdosa (2011b), wskazały na powstanie parafii frydmańskiej w drugiej połowie XIII wieku podczas cysterskiej kolonizacji doliny Dunajca. Tezę potwierdzają badania Jerzego Gadomskiego, datujące powstanie zrębu budowli na przełomie wieków XIII i XIV (Szyma, 2011). Na podstawie badań okna zakrystii i wspornika stwierdzono, że budynek przeszedł w średniowieczu dwa etapy budowlane, około 1253 oraz 1300 roku. Wykonane w 2009 roku badania archeologiczne odnotowały obecność murowanego kościoła otoczonego kamiennym murem z XIV/XV wieku, potwierdzając refugialną rolę budynku (Niemiec, 2011). Pomimo braku jednoznacznych informacji określających czas powstania kościoła oraz jego pierwotną formę badania stwierdzają, iż świątynia jako wyraz potrzeb religijnych osadników funkcjonowała w osadzie przed lokacją węgierską. Wprowadzając zasady rozplanowania niwowego - dostosowane do miejscowych uwarunkowań lokalnych, w tym przebiegu szlaków i sieci wodnej - inkorporowano funkcjonowanie lokalnej świątyni w strategicznym miejscu układu, lokalizując ją we wschodniej części nawsia. Większą zmianę w rozplanowaniu, podkreślającą znaczącą rolę Frydmana na tle regionu, przyniosła w XVI wieku budowa folwarku obsługiwanego przez miejscową ludność oraz najemnych żelarzy (Karczmarzewski, 1966)³.

Historycznie frydmański kościół należał najpierw do diecezji krakowskiej, przechodząc później do katolickiej prepozytury spiskiej. W XV wieku parafia, jako znacząca w regionie, objęła częściowo nowo powstałe kościoły w Krempachach i Nowej Białej, Dursztynie, Jurgowie, Trybszu oraz Falsztynie pod koniec XVIII wieku. W XIX wieku pozostał on, oprócz frydmańskich przysiółków, jedyną wsią parafialną. W 1584 roku miejscowa szlachta wyznania luterańskiego ustanowiła parafię ewangelicko-augsburską, która funkcjonowała do 1640 roku. Nawróceni na katolicyzm właściciele sprowadzili polskich księży powiązanych z prepozyturą spiską, co wpłynęło znacząco na podniesienie zasobności lokalnego kościoła. Nie mając pierwotnie nadanych fundacji, parafia - zajmująca budynek świątyni z cmentarzem w granicach ogrodzenia oraz plebanię z ogrodem - utrzymywała się długo głównie z ofiar wiernych. W następnych wiekach pleban zyskał kolejne pola i ogrody z zabudowaniami gospodarczymi oraz obsługujących je żelarzy. We współpracy z właścicielem wsi organizował ochronę zdrowia i edukację, wpływając

3 Nazwa pochodziła od węgierskiego słowa „zseller” oznaczającego bezrolnego chłopa pańszczyźnianego. 
pośrednio na zmiany we wsi. Historycznie najwcześniej powstała szkoła zarządzana przez kościelnego nauczyciela. Następnie, w 1832 roku, do personelu parafialnego dołączyli także grabarz i akuszerka. W 1771 roku na gruntach sąsiadujących z kościołem od wschodu wzniesiono szpital ubogich, który, wraz z plebanią oraz szkołą, spłonął w 1929 roku. Zrekonstruowano tylko budynki gospodarcze oraz plebanię, która w 1946 roku została poddana kolejnym przekształceniom w dotychczasowym miejscu. Okres powojenny przyniósł zmiany własnościowe w obrębie dóbr kościelnych, częściowo wykupionych na cele publiczne. Historycznie przy kościele wyznaczony był cmentarz parafialny, który na skutek przeludnienia oraz austriackich reform sanitarnych w 1800 roku został przeniesiony poza zabudowę, w obecne miejsce. Przy głównych drogach powstawały kapliczki jako lokalne miejsca modlitwy oraz upamiętnienia wydarzeń. Fundatorami kaplic pełniących okresowo rolę obiektów mszalnych (pw. św. Floriana czy pw. Spotkania Matki Bożej z Elżbietą) była miejscowa szlachta inspirowana przez plebana. Budynek kościoła, zachowując niezmiennie swoją lokalizację oraz orientację, był przebudowywany i rozbudowywany z fundacji kościelnych i szlacheckich, zgodnie z ówczesnymi wytycznymi stylistycznymi. W 1751 roku nowy pleban przebudował wnętrze w stylu barokowym, postawił wieże bramne w ogrodzeniu kościoła oraz dobudował od strony północnej kaplicę Matki Boskiej Karmelitańskiej.

Analizy porównawcze układu XIX-wiecznego zdjęcia józefińskiego ${ }^{4}$ ze stanem aktualnym wsi (il. 2) potwierdzają bardzo dobre zachowanie historycznego układu, położenia kościoła parafialnego oraz rozplanowania funkcji w terenie względem głównych dróg. Do dziś utrzymały się zabudowania kościelne, w tym plebania oraz budynek dawnego przedszkola

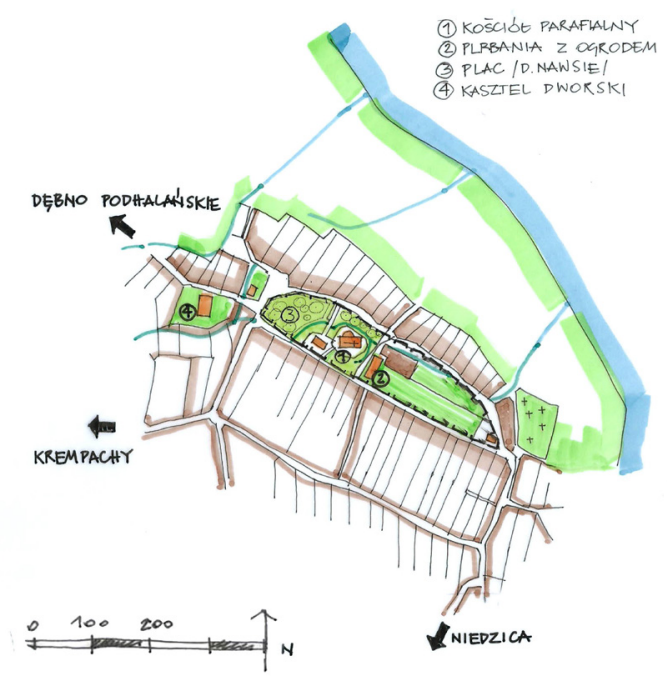

II. 2. Centrum wsi Frydman z zaznaczeniem kościoła oraz strefy ochrony konserwatorskiej w obrębie nawsia. Oprac. własne według mapy zasadniczej z zasobów Starostwa Powiatowego w Nowym Targu oraz badań własnych

\footnotetext{
4 Mapa sporządzona przez władze austriackie w latach 1779-1783, dostępna w formie cyfrowej na portalu mapowym www.mapire.eu (dostęp: 30.03.2021).
} 
używany obecnie jako dom pogrzebowy. Działki obiektów straconych w pożarze zabudowano domami mieszkalnymi. Rozwój wsi objął nową zabudowę jednorodzinną wzdłuż głównych dróg, bazujących na historycznych przebiegach w kierunku wschodnim i zachodnim. Wolne od zabudowy, jako plac rekreacyjny, pozostało nawsie, nazwane Placem Tysiąclecia.

Kościół pw. św. Stanisława Męczennika niezmiennie znajduje się na historycznym nawsiu (Placu Tysiąclecia). Budynek z 1760 roku jest jednonawowy, murowany z miejscowego, łamanego piaskowca, tynkowany na elewacjach i we wnętrzu oraz nakryty dwuspadowym dachem. Od zachodu bryłę osiowo zamyka wieża zwieńczona późnorenesansową attyką, natomiast od północy ośmioboczna kaplica. Całość założenia jest ogrodzona kamiennym, tynkowanym murem z dwiema bramami oraz dzwonnicą. Nieużywany cmentarz przykościelny pełni obecnie funkcję urządzonego zielenią placu procesyjnego. Zachował się także w większości przebieg otaczającej fosy z młynówką oraz działki ogrodowe. Koło kościoła znajduje się murowana plebania z ogrodem. Wieża kościoła stanowi mocną dominantę wysokościową w panoramie oraz lokalnie w wydzielonym placu, zamykając główne ciągi widokowe układu zabudowy (II. 3).

Kościół wraz z ogrodzeniem i dzwonnicą został wpisany w 1956 roku do Rejestru Zabytków Nieruchomych Województwa Małopolskiego ${ }^{5}$. Poza nim ochroną został objęty kasztel pozostały po folwarku. Do gminnej ewidencji zabytków wpisane są ponadto obiekty z otoczenia kościoła, w tym plebania oraz kapliczki ${ }^{6}$.

Obszar administracyjny wsi od 2006 roku jest pokryty w całości zapisami miejscowego planu zagospodarowania przestrzennego ${ }^{7}$, który utrzymał wszystkie obiekty kultu religijnego, nie wskazując nowych. Zgodnie $z$ wymogami ustawowymi ${ }^{8}$ plan wprowadził strefy ochro-

II. 3. Widok na kościół we Frydmanie od strony zachodniej, Placu

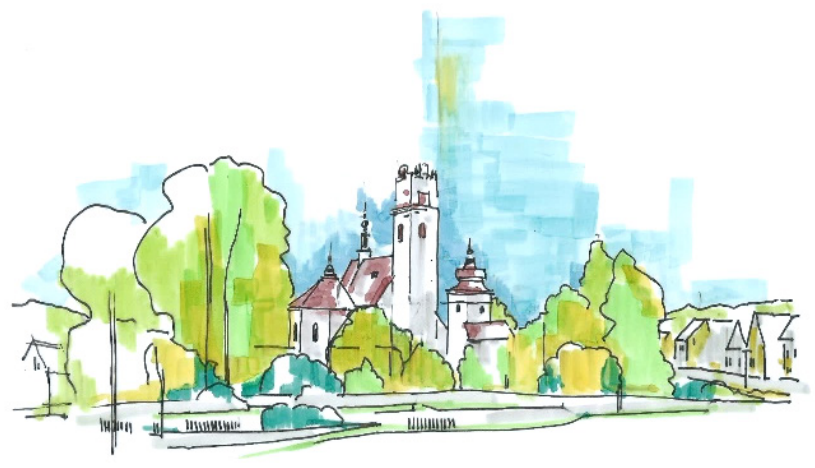

Tysiąclecia. Oprac. własne

5 Decyzja nr A-345 z 5.11.1956 (A-824/M). Źródło: Wojewódzki Urząd Ochrony Zabytków w Krakowie według stanu na lipiec 2020 roku (https://www.wuoz.malopolska.pl/rejestrzabytkow/).

Źródło: Delegatura WKZ w Nowym Targu. Stan na dzień 06.06.2020.

Uchwała Rady Gminy Łapsze Niżne Nr XXXVIII-210/2006 z dnia 27 kwietnia 2006 r.

8 Art. 15, ust. 2, pkt 4 Ustawy z dnia 27 marca 2003 r. o planowaniu i zagospodarowaniu przestrzennym (Dz.U. $2003 \mathrm{Nr} 80$, poz. 717 z późn. zm.). 
ny konserwatorskiej „A” dla obiektów wpisanych do rejestru zabytków oraz strefę ochrony konserwatorskiej „B” (otuliny) dla terenu historycznego nawsia w jego lokacyjnym zakresie.

Podobnymi do Frydmana morfologicznie strukturami są sąsiadujące od zachodu Nowa Biała i Krempachy, lokowane pod koniec XIV wieku, również z inicjatywy węgierskiej szlachty na prawie magdeburskim. Brak potwierdzonych wcześniejszych śladów formalnego osadnictwa w tych ośrodkach wskazuje, iż parafie powstały w okresie rozwoju lokacyjnych wsi (Budz, 1999), pozostając wraz z lokalnymi szkołami pod zwierzchnictwem parafii frydmańskiej.

Obecny kościół pw. św. Marcina w Krempachach został zbudowany w pierwszej połowie XVI wieku. Jego forma, stojąca na historycznym nawsiu, podobna do kościoła frydmańskiego, jest również zorientowana, kamienna i tynkowana, zakończona od zachodu wysoką prostokątną wieżą z murowaną attyką i hurdycją. Teren kościoła z dawnym cmentarzem otacza kamienny mur z bramami. Kościół w Nowej Białej, pw. św. Katarzyny Aleksandryjskiej, jest chronologicznie nowszy. Jego obecna forma, z połowy XVIII wieku, powstała na nawsiu od strony drogi z Łopusznej do Krempach jako odbudowana z inicjatywy mieszkańców po pożarze. Jest to orientowany, murowany budynek, do którego prowadzi wejście od zachodu przez wysoką wieżę na rzucie kwadratu, zwieńczoną barokowym chełmem. Oba kościoły mają w swoim sąsiedztwie plebanie oraz parkingi na odwiedzających.

Rozplanowania wsi, kontynuujące cechy historyczne, są znacznie mniej regularne od frydmańskiego, dostosowane do przebiegu szlaków, a ich nawsia są częściowo zabudowane usługami (Krempachy) oraz budynkami mieszkalnymi (Nowa Biała). Oba kościoły zostały wpisane do Rejestru Zabytków Nieruchomych Województwa Małopolskiego ${ }^{9}$. Ponadto w historycznych strukturach funkcjonuje wiele zewidencjonowanych zabytków, głównie domów zagrodowych, świadcząc o trwaniu historycznej struktury.

Analiza historycznego umiejscowienia kościoła w strukturze wskazuje centrotwórczy wpływ na przestrzeń publiczną powiązaną z ponadlokalną drogą. Przez nią, pośrednio, trwanie jako część układu wpływa także na zachowanie, linię zabudowy mieszkaniowej oraz rozplanowanie działek siedliskowych, utrzymując podział strefowy.

\section{CZARNA GÓRA}

Wieś Czarna Góra, należąca do gminy Bukowina Tatrzańska w powiecie tatrzańskim, jest jedną z granicznych wsi polskiego Zamagurza, sąsiadując od zachodu z podhalańskimi Bukowiną Tatrzańską i Białką Tatrzańską, natomiast od południa z Jurgowem, a od północy i wschodu z ośrodkami gminy Łapsze Niżne. Podstawą gospodarki Czarnej Góry jest rozwijająca się turystyka, która zastąpiła historyczne pasterstwo.

Decyzje nr A-747 z 15.06.2001 [A- 91/M] (Kościół par. pw. św. Katarzyny, cmentarz przykościelny, ogrodzenie) oraz nr A-749/94 z 26.06.1994 (NS) [A-876/M] (Kościół par. pw. św. Marcina z ogrodzeniem). Źródło: https:// www.wuoz.malopolska.pl/rejestrzabytkow/ (dostęp: 03.2021). 
Słownik geograficzny Królestwa Polskiego i innych krajów słowiańskich opisuje Czarną Górę następująco: „ «Czarnagóra», węg. "Csarnagura, Fegetyhegy», wś słowacka na Spiżu, w części podtatrzańskiej; rozległa nad potokiem Grabką, płynącym ku północy i wpadającym z pr. brz. do Białki, tuż przy granicy nowotarsko-spiskiej. (...) Osada ta istniała już w r. 1297 pod nazwą «Clara Vallis» (...). Ludność katolicka liczy 644, a żydów 13 (...)” (Sulimierski i in., 1880: 738).

Za początek osadnictwa wsi uważa się przybycie w XV wieku z Bałkanów Wołochów (Złahoda, 1995), którzy idąc doliną Białki, zatrzymali się w okolicach dzisiejszego przysiółka Sołtystwo. Na początku XVII wieku ${ }^{10}$, wykorzystując ich obecność, szlachta węgierska przeprowadziła formalną lokację na prawie wołoskim. Indywidualnie wydzielone zarębki zaczęła powoli zamieszkiwać, oprócz ludności lokalnej, ludność przybywająca od strony Trybsza. Jednocześnie zaczęła się zaludniać południowa dolina Białki, głównie przez osadników z Małopolski i Podhala. Dwie strefy osiedleńcze, rozdzielone przełęczą Sołtystwo, rozwijały się oddzielnie na bazie połączeń drogowych z Trybszem (Zagóra) oraz Jurgowem i Bukowiną Tatrzańską (Pod Górą). Część północna, Zagóra, zachowała cechy historycznego rozplanowania typu łanowego, natomiast część południowa została przekształcona w typ niwowy.

Pierwotnie w ciągu indywidualnych podziałów nie przewidziano usług ani przestrzeni publicznych, które wykształciły się później jako niepowiązane z lokalnym kościołem. Powstawały z prywatnej inicjatywy lub wprowadzane były przez władze zwierzchnie (Złahoda, 2011) ${ }^{11}$. Ludność, w większości wyznania katolickiego, należała do parafii w Trybszu, przynależącej do Opactwa Cystersów w Mogile ${ }^{12}$. Pierwsza czarnogórska świątynia powstała w obecnej lokalizacji,

II. 4. Widok kościoła w Czarnej Górze

- Zagórze od strony północnej. Oprac. własne

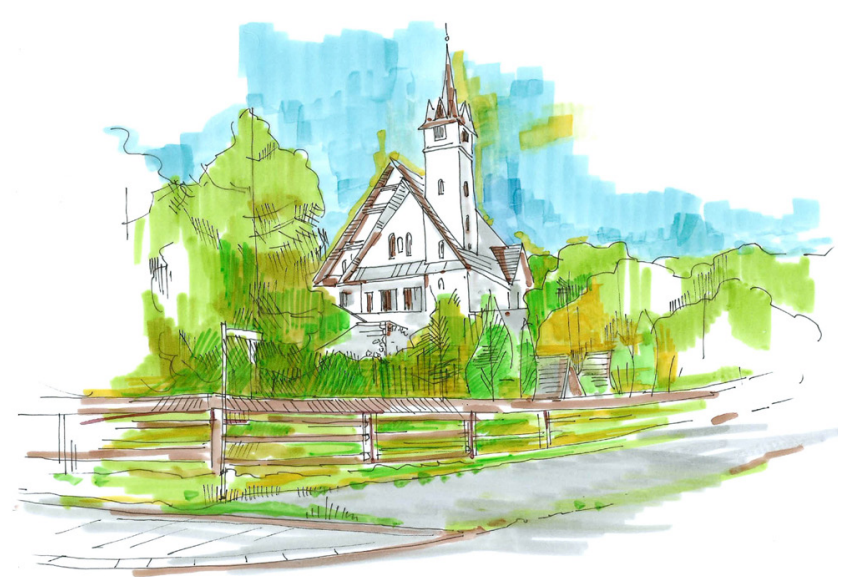

10 Dokładna data nie jest znana, ponieważ nie zachował się dokument lokacyjny.

11 Oprac. na podstawie badań dokumentów źródłowych, w tym kronik szkolnych. Pierwsza szkoła rozpoczęła funkcjonowanie w 1850 roku w prywatnym domu. W 1911 roku rząd węgierski nakazał budowę dwóch odrębnych szkół dla poszczególnych części wsi, powstałych w 1914 i 1915 roku nakładem finansowym mieszkańców.

12 Mieszkańcy części Pod Górą uczęszczali głównie do parafii w Jurgowie. 


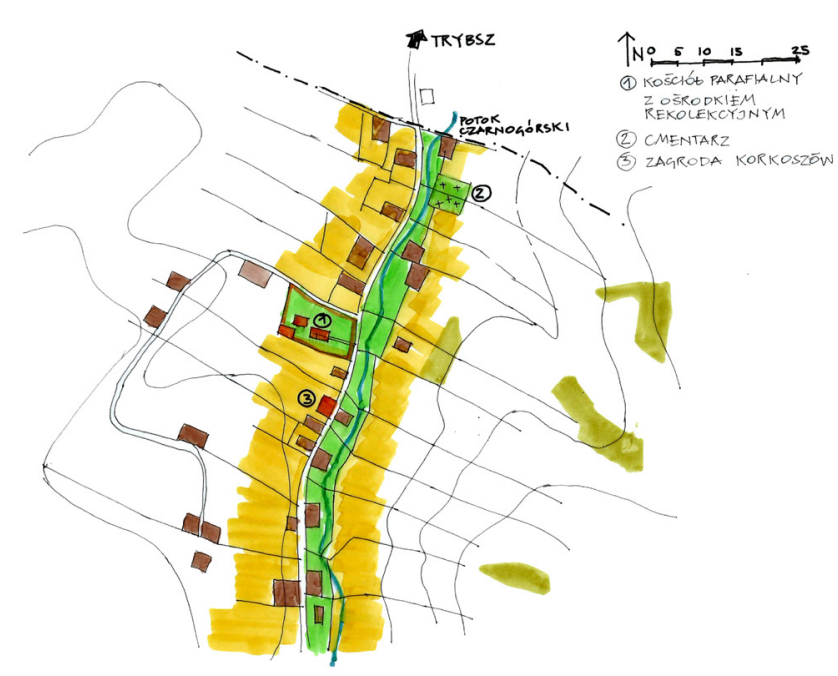

II. 5. Obecne zagospodarowanie północnej części obszaru Czarna Góra - Zagóra w sąsiedztwie kościoła. Oprac. własne na podstawie mapy topograficznej ze Starostwa Powiatowego w Zakopanem oraz badań własnych

jako filialna, w 1948 roku z inicjatywy mieszkańców na przekazanej przez nich działce ${ }^{13}$. Był to mały kamienny kościółek, który później rozbudowano i dobudowano do niego plebanię. Obecna forma kościoła w Zagórze (pw. Przemienienia Pańskiego) pochodzi z 1995 roku. Murowana, niezorientowana budowla znajduje się na ogrodzonym terenie (il. 4), na którym od strony drogi urządzono zielony teren procesyjny ze schodami prowadzącymi po zboczu. Na terenie funkcjonuje duży ośrodek rekolekcyjny. Po drugiej stronie drogi został wydzielony cmentarz parafialny.

Analiza obecnego zagospodarowania Czarnej Góry - Zagóry (il. 5) wskazuje na zachowanie historycznego przebiegu głównej drogi oraz dróg gospodarczych i intensyfikującą się wzdłuż nich zabudowę, kolejno zagrodową, jednorodzinną oraz pensjonatową i usługową. W badanym obszarze nie ma zabytkowych obiektów kultu, natomiast do ewidencji gminnej zostało wpisanych siedem zabudowań zagrodowych ${ }^{14}$, z których Zagroda Korkoszów jest wpisana do rejestru i użytkowana jako Muzeum Zagrody Korkoszów ${ }^{15}$. Obszar administracyjny wsi od 2006 roku $^{16}$ jest pokryty zapisami miejscowego planu zagospodarowania przestrzennego, który utrzymał historyczną strukturę, poszerzając znacząco zakres turystycznego zainwestowania na tereny wschodnich wzniesień. W zakresie ochrony zabytków wskazano strefę ochrony konserwatorskiej „A" dla wpisanej do zespołu Zagrody Korkoszów oraz strefę „ $B$ ” dla jej otuliny oraz historycznego przysiółka Sołtystwo. W szerszym ujęciu wprowadzono strefę ochrony krajobrazu kulturowego „K”, obejmującą niezabudowane przestrzenie rolno-leśne.

13 http://czarnagora24.pl/instytucje-i-organizacje/parafie/kosciol-pw-przemienienia-panskiego/ (dostęp: 30.03.2021).

14 Źródło: Wojewódzki Urząd Ochrony Zabytków w Krakowie. Delegatura w Nowym Targu. Stan na 26.06.2020 r.

15 Decyzje nr A-703 z 26.10.1993 [A-816/M].

16 Uchwała Nr XLIII/344/2006 Rady Gminy Bukowina Tatrzańska z dnia 27 października 2006 r. w sprawie miejscowego planu zagospodarowania przestrzennego Czarna Góra - Gmina Bukowina Tatrzańska. 
Podobna do Czarnej Góry pod względem łanowej struktury jest położona od niej na wschód zamagurska wieś Łapszanka, która powstała w XVII wieku jako przysiółek wsi Łapsze Wyżne (Budz, 1999) w dolinie potoku Łapszanka. Analogicznie jak w Czarnej Górze usługi powstały tutaj na początku XX wieku, kiedy z inicjatywy mieszkańców w latach 1901-1909 wybudowano kościół pw. Najświętszego Serca Pana Jezusa jako filię parafii Łapsze Wyżne ${ }^{17}$. Zorientowany na zachód, ogrodzony obiekt stoi podobnie jak w Czarnej Górze przy głównej drodze. W 1903 roku powstał budynek publicznej szkoły podstawowej, która jest jednym z zabytków zewidencjonowanych - oprócz ośmiu zabudowań zagrodowych, trzech kapliczek oraz dwóch budynków gospodarczych ${ }^{18}$.

\section{WNIOSKI. POWIAZZANIE STRUKTURY Z FUNKCJONOWANIEM LOKALNEGO KOŚCIOŁA}

Analiza cech przedstawicieli odmiennych morfologicznie struktur wiejskich wskazuje na znaczące różnice w zakresie powstania i funkcjonowania lokalnych parafii oraz, jednocześnie, punkty wspólne w postaci czynników uniwersalnych i ponadlokalnych.

We wszystkich strukturach powstanie oraz zasady rozplanowania i funkcjonowania kształtowały miejscowe uwarunkowania fizjograficzne. Osadnictwo jako pierwsze pojawiło się wzdłuż naturalnie wytworzonych szlaków komunikacyjnych w szerokich dolinach rzeki Białki i Dunajca, którymi rozchodziła się kolejno kolonizacja cysterska. Granice terenowe wyznaczały ważne kolonizacyjnie terytorium graniczne. W powstających układach centrycznych kościół pod względem przestrzennym od początku był centrum skoncentrowanej dośrodkowo społeczności, integrując ją i wspomagając jej rozwój. Tymczasem wąskie górskie doliny potoków południowego Zamagurza, trudniejsze w użytkowaniu, pozostawały długo poza obszarem działań kolonizatorskich, rozwijając się liniowo bez przestrzeni wspólnych. Fizjonomia przestrzeni wpłynęła zatem na przesunięcie miejsca integracji społeczności, skupionej wokół kościoła, poza obszar wsi do sąsiedniej parafii.

We wszystkich wsiach znaczący był wpływ czynnika ludzkiego i potrzeb duchowych lokalnej wspólnoty. Parafie zakładane były przez instytucje kościelne i zakonne, aby zaspokoić potrzebę wiary lokalnej społeczności i przy jej czynnym udziale. Obecnie pod względem uwarunkowań funkcjonowania zachowała się własność terenu oraz źródło utrzymania, którym są nadal głównie składki parafian i subwencje kościelne. Zmieniło się znacząco pierwotne powiązanie z usługami, które wraz ze zmianami gospodarczo-społecznymi są organizowane przez sektor państwowy lub prywatny. Budynki świątyń wciąż pozostają mocnymi dominantami przestrzennymi, podkreślając rangę lokalnego kościoła w szerokiej panoramie. Parafie powstałe w XX wieku z inicjatywy mieszkańców - na działkach wybranych ze względów

\footnotetext{
17 https://lapsze.saletyni.pl/?page_id=1621 (dostęp: 30.03.2021).

18 Źródło: Wojewódzki Urząd Ochrony Zabytków w Krakowie. Delegatura w Nowym Targu. Stan na 26.06.2020 r.
} 
własnościowych, a nie funkcjonalnych czy ich miejsca w strukturze i kompozycji wsi - wpisały się w indywidualne rozplanowanie, będąc dominantami lokalnymi. Znaczące były w tych przypadkach istniejące powiązania regionalne z sąsiednimi parafiami, które przejmując własności ziemskie, rozwijały parafię przy udziale mieszkańców. Wsie posiadające inicjalnie własne centra lokalne z kościołem rozwijały się wspólnotowo, jako zintegrowane do wewnątrz, natomiast w ośrodkach rozproszonych życie religijne parafii skupiało się długo na zewnątrz struktury. Do dziś we wszystkich przykładach utrzymało się zaangażowanie lokalnej wspólnoty w życie kościoła i utrzymanie jego budynków jako jednego z najważniejszych miejsc w życiu mieszkańców.

W układach niwowych historyczny rozwój przestrzenny wsi nie zatarł głównych powiązań w wyznaczonych inicjalnie strefach. Można to przypisywać ich mocnemu osadzeniu w ulegających niewielkim zmianom uwarunkowaniach terenu, powiązanych z układem drogowym i pierwotnym podziałem własności, kształtującym zależności na działkach. W przyrastających pasowo łanowych strukturach zmiany zagospodarowania działki kościelnej nie miały wpływu na szersze otoczenie, ograniczając się do aranżacji odcinka drogi i pobliskiego cmentarza.

Lokalizacja świątyni oraz czas jej powstania miały bezpośredni wpływ na jej położenie na działce. Kościoły Frydmana czy Krempach (Korzeniowska, 2021), projektowane na płaskim terenie, realizowały powszechne wówczas zasady orientacji prezbiterium w kierunku wschodnim. Tej historycznej orientacji nie wprowadzono już w XX-wiecznym kościele w Czarnej Górze, gdzie wpisując się w funkcjonującą już strukturę, dostosowano ułożenie do możliwości terenowych działki.

Formalna ochrona zabytków w zakresie kościoła, utrzymując funkcję w miejscu, zachowuje formę oraz aranżację otoczenia, a szerzej powiązania przestrzenne w strukturze. Zapisy chroniące formę jako świadectwo historyczne wskazują optymalne działania remontowe wykonywane przy udziale niezmiennie zaangażowanej społeczności. Objęcie ochroną pozwala na odpowiednie finansowanie remontów. Promocja zabytku podnosi ponadto rangę miejsca jako dochodowej atrakcji turystycznej, wpływając na zmiany wsi w obrębie obszaru rekreacji, handlu i usług.

\section{PODSUMOWANIE}

Przeprowadzone analizy struktur wiejskich Zamagurza wskazują zdecydowanie różnice w powstaniu i funkcjonowaniu ośrodków kościelnych, wynikające z odmiennych uwarunkowań miejsca, obejmujących uwarunkowania terenowe i powiązania regionalne kształtujące odmienne struktury i wspólnoty osadnicze. Wszystkie wsie łączy funkcja kościoła jako miejsca kultu religijnego, wzmacniającego więzi społeczności lokalnych i regionalnych, potwierdzając wpisane w teren granice wytworzone przez powiązania drogowe czy administracyjne. Pomimo rozbieżności jednym z najważniejszych czynników kształtujących miejsce kościoła 
w wiejskiej strukturze jest potrzeba społeczności lokalnej, która każdorazowo, w odmiennych uwarunkowaniach, doprowadzała do powstania i utrzymania parafii. Jej siedziba stawała się kolejno integralnym elementem przestrzeni, wchodząc w nowe interakcje z pozostałymi elementami struktury tworzonej przez mieszkańców, przyrodę i cywilizację.

\section{BIBLIOGRAFIA}

Bukraba-Rylska, I. (2013). Socjologia wsi polskiej. Warszawa: PWN.

Budz, J. (1999). Zamagurze Spiskie/Spišské Zamgurie. Kraków: Oficyna Artystów „Sztuka”.

Burszta, J. (1958). Od osady słowiańskiej do wsi współczesnej. Wrocław: Zakład Narodowy im. Ossolińskich.

Burszta, J. (1954). Zagadnienie „nawsia” w osadnictwie wiejskim. Lud, 41, 439-498.

Chowaniec, M. (1986). Zarys teorii i zasad kształtowania osiedli i terenów wiejskich. Kraków: Politechnika Krakowska.

Danilczyk, L., Krasnowolski, B., Niewalda, W. (1989). Studium historyczno-konserwatorskie rejonu budowy zbiorników wodnych w Czorsztynie i Niedzicy oraz Sromowcach Wyżnych, z. 12: Frydman. Kraków: PKZ o. Kraków, zasoby NID.

Grabski, M. (2012). Architektura sakralna. W: U. Janicka-Krzywda (red.), Kultura ludowa Górali Spiskich (s. 109-144). Kraków: COTG PTTK.

Janicka-Krzywda, U. (red.) (2012). Kultura ludowa Górali Spiskich. Kraków: COTG PTTK.

Janicka-Krzywda, U., Słabosz-Palacz, K., Rak, M. (red.) (2011). Dzieje wsi Frydman. Pobrane z: http://frydman.com.pl/dokumenty/dzieje_wsi_frydman.pdf (dostęp: 03.07.2020).

Karczmarzewski, A. (1966). Półfeudalne stosunki gospodarczo-społeczne (instytucja żelarstwa) oraz ich kulturowe następstwa w niektórych wsiach Polskiego Spisza w drugiej połowie XIX i w XX wieku. Praca magisterska, mpis. Kraków: Archiwum Instytutu Etnologii i Antropologii Kulturowej UJ, nr arch. 57.

Kornecki, M. (1992). Drewniana architektura sakralna w Polsce. Zagadnienie typów i form regionalnych w rozwoju historycznym. Ochrona Zabytków, 45/1-2(176-177), 7-31. Pobrane z: http://bazhum.muzhp.pl/media//files/Ochrona_Zabytkow/Ochrona_Zabytkow-r1992-t45-n1_2_(176_177)/Ochrona_Zabytkow-r1992-t45-n1_2_(176_177)-s7-31/ Ochrona_Zabytkow-r1992-t45-n1_2_(176_177)-s7-31.pdf (dostęp: 10.03.2021).

Korzeniowska, A. (2021). Rola i znaczenie tradycji miejsca w rozwoju przestrzennym wsi na przykładzie Zamagurza Spiskiego. Praca doktorska, mpis. Kraków: Katedra A5, WA PK.

Niemiec, D. (2011). Badania archeologiczne we Frydmanie na Spiszu w latach 2009-2010. W: U. Janicka-Krzywda, K. Słabosz-Palacz, M. Rak (red.), Dzieje wsi Frydman (s. 11-14). Pobrane z: http://frydman.com.pl/dokumenty/dzieje_wsi_frydman.pdf (dostęp: 03.07.2020). Radziszewska, J. (1985). Studia spiskie. Katowice: Uniwersytet Śląski.

Solecki, A. (1966). Pasmowo-zwarta struktura osiedli na Spiszu Polskim w świetle przemian gospodarczych wsi. Praca doktorska, mpis. Kraków: WA PK. 
Szulc, H. (1995). Morfogeneza osiedli wiejskich w Polsce. Wrocław: IGiPZ PAN.

Szyma, M. (2011). Architektura kościoła we Frydmanie a początki najstarszej wsi polskiego Zamagurza. W: U. Janicka-Krzywda, K. Słabosz-Palacz, M. Rak (red.), Dzieje wsi Frydman (s. 57-72). Pobrane z: http://frydman.com.pl/dokumenty/dzieje_wsi_frydman.pdf (dostęp: 03.07.2020).

Sulimierski, F., Chlebowski, B., Walewski, W. (1880). Słownik geograficzny Królestwa Polskiego i innych krajów słowiańskich, t. I. Warszawa. Pobrane z: http://dir.icm.edu.pl/ Slownik_geograficzny/Tom_II/419 (dostęp: 30.03.2020).

Trajdos, M.T. (1991). Szkice z dziejów Zamagurza. Kraków: Secesja.

Trajdos, M.T. (2011a). Z dziejów wsi i parafii Zamagurza Spiskiego. Łapsze Niżne.

Trajdos, M.T. (2011b). Parafia i życie religijne we Frydmanie do 1832 roku. W: U. Janicka-Krzywda, K. Słabosz-Palacz, M. Rak (red.), Dzieje wsi Frydman (s. 15-56). Pobrane z: http://frydman.com.pl/dokumenty/dzieje_wsi_frydman.pdf (dostęp: 03.07.2020).

Uchwała Nr XLIII/344/2006 Rady Gminy Bukowina Tatrzańska z dnia 27 października 2006 r. w sprawie miejscowego planu zagospodarowania przestrzennego Czarna Góra - Gmina Bukowina Tatrzańska.

Uchwała Rady Gminy Łapsze Niżne Nr XXXVIII-210/2006 z dnia 27 kwietnia 2006 r.

Ustawa z dnia 27 marca 2003 r. o planowaniu i zagospodarowaniu przestrzennym (Dz. U. 2003 Nr 80, poz. 717 z późn. zm.).

Złahoda, B. (1995). Dzieje Czarnej Góry do 1939 roku. Praca magisterska, mpis. Kraków: WSP. www.frydman.com.pl/zakladka_1/(dostęp: 10.03.2021).

www.frydman.com.pl/parafia/ (dostęp: 30.03.2021).

www.mapire.eu (dostęp: 30.03.2021).

www.geportal.gov.pl. (dostęp: 30.03.2021).

www.polskawliczbach.pl (dostęp: 30.03.2021).

www.wuoz.malopolska.pl/rejestrzabytkow/ (dostęp: 03.03.2021).

www.lapsze.saletyni.pl/?page_id=1621 (dostęp: 30.03.2021). 